\title{
Ionium dating of acidic volcanic rocks*
}

\author{
TAKAAKI FUKUOKA \\ Department of Chemistry, Faculty of Science, Gakushuin \\ University, Mejiro, Tokyo 171, Japan
}

(Received April 23, 1974)

\begin{abstract}
Concentrations of uranium, and concentrations and isotopic ratios of thorium in zircon and glass were determined for pyroclastic dacite pumices in southern Kyushu, Japan, and Io-ages were calculated. Uranium and thorium distributions in other minerals were also determined.

Uranium and thorium contents of minerals were highest for zircon and decreased in the order, zircon-apatite-glass-mafic minerals-plagioclase. Zircons showed the highest $\mathrm{U} / \mathrm{Th}$ activity ratios compared with other minerals.

Io-ages obtained by glass-zircon pair for pyroclastic flows in southern Kyushu, except for Ata pyroclastic flow were consistent with ${ }^{14} \mathrm{C}$ and fission track ages and the stratigraphic sequence. Comparison of uranium and thorium concentrations in mineral constituents of acidic volcanic rocks showed that the glass-zircon pair is the most preferable for ionium dating.
\end{abstract}

\section{INTRODUCTION}

Ages of volcanic activities in the late Quaternary have been determined mostly by radiocarbon dating. The use of radiocarbon dating, however, is limited to samples younger than about $40,000 \mathrm{y}$ because of the relatively shorter half-life of ${ }^{14} \mathrm{C}$. Recently the fission track dating method (Shima, 1967; SuzuKI, 1970; YabuKi and Shima, 1970; KANEOKA and SuzuKI, 1970) and the K-Ar dating method (KANEOKa and SuzUKI, 1970) were applied to the dating of volcanic rocks of the late Quaternary. However, these two methods often include considerably larger errors for late Quaternary samples than for older ones, owing to the long half-lives of radioactive nuclides involved.

Ionium $\left({ }^{230} \mathrm{Th}\right.$ ), decaying with its half-life of 75,200y (ATTREE et al., 1962), appears to be a useful tool for the dating of late Quaternary events ranging in age from several thousand to about $200,000 \mathrm{y}$. However, the ionium dating which can give more accurate dates than fission track or K-Ar datings has been carried out only on the samples of pelagic sediments (GoLdBERG and KoIDE, 1962) and corals (KAUfMAN et al.,

* This study has been undertaken in partial fulfillment for the degree of Doctor of Science at Gakushuin University. 
1971). Cerrai et al. (1965) first attempted to apply ionium dating to volcanic products. Kigoshi (1967) independently developed a similar dating method for igneous rocks and also TADDEUCCI et al. (1967) reported ${ }^{230} \mathrm{Th}$ dating of volcanic rocks. More recently, KUPTSOV et al. (1969) attempted ionium dating of young volcanic rocks.

The method and its fundamental requirements for ionium dating of volcanic rocks were extensively described in Kigoshi (1967) and FukUOKA and KIGOSHI (1970). Io-age $(t)$ of volcanic rocks is given by

$$
t=\frac{1}{\lambda} \ln \left[1 /\left(1-\frac{Y_{1}-Y_{2}}{X_{1}-X_{2}}\right)\right]
$$

where $Y_{1}$ and $Y_{2}$ are $\operatorname{Io}\left({ }^{230} \mathrm{Th}\right) / \mathrm{Th}\left({ }^{232} \mathrm{Th}\right)$ activity ratios in minerals (1) and (2) separated from a same rock, respectively; $X_{1}$ and $X_{2}$ are $\mathrm{U}\left({ }^{238} \mathrm{U}\right) / \mathrm{Th}\left({ }^{232} \mathrm{Th}\right)$ activity ratios in minerals (1) and (2), respectively; and $\lambda$ is the decay constant of ${ }^{230} \mathrm{Th}$. The accuracy of age $t$ calculated from Eq. (1) depends on the difference between $X_{1}$ and $X_{2}$ as well as uranium and thorium contents of mineral phases. Therefore, the most accurate ages will be obtained by the mineral pair having the largest difference in $\mathrm{U} / \mathrm{Th}$ activity ratios.

To find out the pair of $X_{1}$ and $X_{2}$ which gives the most accurate age, we analyzed uranium and thorium in mineral phases separated from pyroclastic dacite pumices. Based on the results, four pyroclastic flows in southern Kyushu have been dated in terms of ionium for glass and zircon pairs. The dating results have been compared with ages by other dating methods and geological evidences.

\section{Samples and Experimental Procedures}

Rock samples used in this study are Kakuto, Ito, Ata, Ikeda and Torihama pyroclastic dacite pumices collected from southern Kyushu, Japan, Yunotani rhyolitic lava of Ontake volcano and Hotokeiwa dacitic lava of Asama volcano in central Honshu, Japan. Geological and mineralogical descriptions of the dacite pumices are given in Aramaki and Ui (1966), AramaKi (1969) and UI (1971), description of the rhyolitic lava is given in K. KOBAYASHI, et al. (1971) and that of the dacitic lava in ARAMAKI (1963).

Each mineral species was separated by using organic heavy liquids and an electromagnetic separator (Frantz Isodynamic Separator). For pumice samples, most of porous glass had been panned off with running water before the separation by an electromagnetic separator and by heavy liquid. Microscopic inspection on the separated zircon and other minerals gave the estimation of the purities of about $99 \%$ and over $95 \%$ respectively. Zircon samples were identified by X-ray diffraction analysis using $\mathrm{Cu} \mathrm{K \alpha _{1 }}(\lambda=1.5405 \mathrm{~A})$ on a Norelco diffractometer.

Uranium and thorium in minerals were determined by the neutron activation 
analysis using a technique similar to that described by WAKITA et al. (1968).

The isotopic ratio of thorium was measured by $\alpha$-ray activity ratio of thorium separated from the sample. For glass samples, 10 to $20 \mathrm{~g}$ of a sample was decomposed with $\mathrm{HF}_{-} \mathrm{HClO}_{4}$. Uranium and thorium were separated in an anion exchange resin column (Dowex 1-X8, $100 \sim 200$ mesh). The thorium fraction was purified by a cation exchange resin column (Dowex 50W-X8, $100 \sim 200 \mathrm{mesh}, 9 \mathrm{~mm} \times 50 \mathrm{~mm}$ ). Finally, the thorium was electroplated on a stainless steel disc of $1.4 \mathrm{~cm}$ diameter. The energy spectrum of alpha rays from thorium isotopes was measured by a solid state detector (surface barrier type). For zircon samples, 2 to $130 \mathrm{mg}$ of a sample was decomposed by borax fusion. Zirconium was removed by precipitation with mandelic acid from $2 \mathrm{~N} \mathrm{HCl}$ solution of the decomposed sample. The analytical procedure after the elimination of zirconium was similar to that described above.

\section{Results AND Discussion}

The results of uranium and thorium analyses are shown in Table 1 with the values of Io/Th activity ratios. The results of six repeated analyses of AGV-1 showed that the errors in uranium and thorium analyses are about $8 \%$ and $4 \%$, respectively. Therefore, over-all errors in uranium and thorium analyses are also believed to be about $8 \%$ and $4 \%$, respectively. A stratigraphic sequence of pyroclastic flows in southern Kyushu (ARAmaKI, 1969; UI, 1971) and its Io-ages are shown in Table 3 together with the ages obtained by other dating methods.

Uranium and thorium contents of minerals are the highest for zircon and decrease in the order, zircon-apatite-glass-mafic minerals-plagioclase (Table 1). Uranium and thorium contents of zircon are 1,000 to 3,000 times higher than those of mafic minerals and plagioclase.

In regard to the difference in U/Th activity ratios of mineral pairs, hornblendezircon, glass-zircon, plagioclase-zircon, and hypersthene-zircon. are largest for Kakuto, Ito, Ata and Ikeda, and Torihama pyroclastic dacite pumices, respectively (Table 1). However, when we consider analytical convenience, the glass-zircon pair is generally the most favorable mineral pair for ionium dating because in most cases volcanic glass has high uranium and thorium contents.

Acidic volcanic rocks usually have large quantities of glass. From the separation yield of zircon from volcanic rocks (Table 2), we can estimate zircon contents of our samples at $1 \times 10^{-5}$ to $2.5 \times 10^{-3} \%$. The separation yield of zircon from Yunotani lava is only about $1 \times 10^{-5} \%$ and no zircon was obtained from Hotokeiwa lava. For these lava samples, the separation of zircon was far more difficult than for pumice samples. The estimated zircon content would be far less than the actual abundance of zircon. The separation yields of palgioclase and mafic minerals are about 0.1 to $0.5 \%$ (calculated from Table 2). For most of acidic volcanic rocks, in order to obtain an 
Table 1. Uranium and thorium contents and $\mathrm{U} / \mathrm{Th}$ and Io/Th activity ratios of minerals separated from pyroclastic dacite pumices in southern Kyushu

\begin{tabular}{|c|c|c|c|c|c|}
\hline Locality & Mineral & $\mathrm{U}(\mathrm{ppm})$ & Th (ppm) & U/Th (activity) & Io/Th (activity) \\
\hline Kakuto & $\begin{array}{l}\text { glass } \\
\text { hornblende } \\
\text { apatite*2) } \\
\text { zircon } \\
\end{array}$ & $\begin{array}{l}1.53 \pm 0.04 \\
0.105 \pm 0.004 \\
7.48 \pm 0.23\end{array}$ & $\begin{aligned} 7.34 & \pm 0.30 \\
0.519 & \pm 0.026 \\
10.3 \pm & 0.5\end{aligned}$ & $\begin{array}{l}0.621 \pm 0.030 \\
0.602 \pm 0.037 \\
2.17 \pm 0.12 \\
3.20 \pm 0.17^{* 3)}\end{array}$ & $0.734 \pm 0.023$ \\
\hline Ito & $\begin{array}{l}\text { glass } \\
\text { plagioclase } \\
\text { hypersthene } \\
\text { apatite*2) } \\
\text { zircon }\end{array}$ & $\begin{aligned} & 2.48 \pm 0.12 \\
& 0.216 \pm 0.007 \\
& 0.476 \pm 0.015 \\
& 8.84 \pm 0.23 \\
& 346 \quad \pm 16\end{aligned}$ & $\begin{array}{l}9.67 \pm 0.44 \\
0.435 \pm 0.018 \\
1.12 \pm 0.05 \\
25.4 \quad \pm 1.0 \\
293 \quad \pm 15\end{array}$ & $\begin{array}{l}0.766 \pm 0.050 \\
1.49 \pm 0.08 \\
1.27 \pm 0.07 \\
1.04 \pm 0.05 \\
3.54 \pm 0.25\end{array}$ & $0.658 \pm 0.021$ \\
\hline Ata & $\begin{array}{l}\text { glass } \\
\text { plagioclase } \\
\text { hypersthene } \\
\text { augite } \\
\text { apatite*2) } \\
\text { zircon }\end{array}$ & $\begin{array}{l}2.07 \pm 0.09 \\
0.128 \pm 0.005 \\
0.0838 \pm 0.004 \\
0.0924 \pm 0.004 \\
2.43 \quad \pm 0.07 \\
763 \quad \pm 13\end{array}$ & $\begin{aligned} & 7.90 \pm 0.35 \\
& 1.04 \pm 0.05 \\
& 0.419 \pm 0.023 \\
& 0.358 \pm 0.019 \\
& 12.2 \pm 0.4 \\
& 1810 \quad \pm 70\end{aligned}$ & $\begin{array}{l}0.783 \pm 0.050 \\
0.369 \pm 0.022 \\
0.599 \pm 0.041 \\
0.772 \pm 0.050 \\
0.595 \pm 0.026 \\
1.26 \pm 0.05\end{array}$ & $1.38 \pm 0.05$ \\
\hline Ikeda & $\begin{array}{l}\text { glass } \\
\text { plagioclase } \\
\text { hornblende } \\
\text { apatite*2) } \\
\text { zircon }\end{array}$ & $\begin{aligned} 2.51 & \pm 0.06 \\
0.0706 & \pm 0.0027 \\
0.404 & \pm 0.014 \\
13.0 & \pm 0.3 \\
226 \quad \pm 5 & \end{aligned}$ & $\begin{array}{rll}10.7 & \pm & 0.7 \\
0.387 & \pm & 0.019 \\
0.956 & \pm & 0.046 \\
24.2 & \pm & 1.1 \\
189 & \pm & 7\end{array}$ & $\begin{array}{l}0.705 \pm 0.046 \\
0.546 \pm 0.034 \\
1.26 \pm 0.08 \\
1.61 \pm 0.08 \\
3.58 \pm 0.16\end{array}$ & \\
\hline Torihama ${ }^{* 1}$ & $\begin{array}{l}\text { glass } \\
\text { plagioclase } \\
\text { hornblende } \\
\text { hypersthene } \\
\text { apatite } \\
\text { zircon }\end{array}$ & $\begin{aligned} 1.79 & \pm 0.05 \\
0.0487 & \pm 0.0017 \\
0.108 & \pm 0.003 \\
0.140 & \pm 0.005 \\
19.7 & \pm 0.6 \\
230 \quad \pm 2 & \end{aligned}$ & $\begin{array}{ccl}8.94 & \pm 0.32 \\
0.250 & \pm 0.012 \\
0.447 & \pm 0.018 \\
1.14 & \pm 0.07 \\
19.8 & \pm 0.8 \\
222 & \pm 10\end{array}$ & $\begin{array}{l}0.599 \pm 0,027 \\
0.583 \pm 0.035 \\
0.723 \pm 0.035 \\
0.369 \pm 0.027 \\
2.98 \pm 0.15 \\
3.10 \pm 0.14 \\
\end{array}$ & $0.663 \pm 0.027$ \\
\hline st & & $1.81 \pm 0,15$ & $6.16 \pm 0.22$ & & \\
\hline
\end{tabular}

Quoted erros are standard deviations calculated from the counting statistics.

*1) Values are derived from FUKUOKA and KIGOSHI (1970).

*2) Values are derived from TEZUKA (1972).

*3) ${ }^{234} \mathrm{Th} /{ }^{232} \mathrm{Th}$ activity ratio (cf. KIGOSHI, 1967).

*4) Averages of six analyses. Quoted errors are standard deviations.

equal amount of uranium (or thorium), the use of plagioclase or mafic minerals requires larger amounts of rock samples than does the use of zircon. Consequently, the use of zircon has the merits in the easy separation and in the simple analytical procedure which is allowed by its high uranium and thorium contents.

Io-ages obtained by the glass-zircon pair are reasonable, except for Ata pyroclastic flow. The Io-age for Ito pyroclastic flow agrees with fission track ages obtained for obsidian samples from Arasaki pumice fall deposits within the range of errors. Though Arasaki pumice fall deposits underlie Ito pyroclastic flow deposits, the time gap between both deposits was not figured out by the dating methods (SATO et al., 1972). Kigoshi et al. (1972) reexamined the samples which gave scattered ${ }^{14} \mathrm{C}$-ages 
Table 2. Approximate separation yields of minerals separated from pyroclastic dacite pumices and lavas

\begin{tabular}{|c|c|c|c|c|c|c|c|c|c|c|c|}
\hline & \multicolumn{11}{|c|}{ Locality } \\
\hline & $\begin{array}{c}\text { Kakuto } \\
\text { (pumice) }\end{array}$ & \multicolumn{2}{|c|}{$\begin{array}{c}\text { Ito } \\
\text { (pumice) }\end{array}$} & \multicolumn{2}{|c|}{$\begin{array}{c}\text { Ata } \\
\text { (pumice) }\end{array}$} & \multicolumn{2}{|c|}{$\begin{array}{c}\text { Ikeda } \\
\text { (pumice) }\end{array}$} & \multicolumn{2}{|c|}{$\begin{array}{l}\text { Torihama } \\
\text { (pumice) }\end{array}$} & $\begin{array}{c}\text { Yunotani } \\
\text { (lava) }\end{array}$ & $\begin{array}{l}\text { Hotokeiwa } \\
\text { (lava) }\end{array}$ \\
\hline $\begin{array}{l}\text { total weight of } \\
\text { separated sample }\end{array}$ & $30 \mathrm{~kg}$ & \multicolumn{2}{|c|}{$73 \mathrm{~kg}$} & \multicolumn{2}{|c|}{$38 \mathrm{~kg}$} & & & \multicolumn{2}{|c|}{$73 \mathrm{~kg}$} & $20 \mathrm{~kg}$ & $>30 \mathrm{~kg}$ \\
\hline $\begin{array}{l}\text { plagioclase } \\
\text { quartz }\end{array}$ & & \multicolumn{2}{|c|}{$4.5 \mathrm{~kg}$} & \multicolumn{2}{|c|}{$2.8 \mathrm{~kg}$} & \multicolumn{2}{|c|}{$2.1 \mathrm{~kg}$} & \multicolumn{2}{|c|}{$17.8 \mathrm{~kg}$} & & \\
\hline $\begin{array}{l}\text { hypersthene } \\
\text { augite } \\
\text { hornblende } \\
\text { magnetite } \\
\text { ilmenite }\end{array}$ & & \multirow[t]{2}{*}{$\begin{array}{l}\infty \\
8 \\
n \\
n\end{array}$} & $150 \mathrm{~g}^{*}$ & \multirow[t]{2}{*}{$\stackrel{\infty}{\infty}_{\infty}^{\infty}$} & $\begin{array}{r}155 \mathrm{~g} * \\
55 \mathrm{~g} *\end{array}$ & \multirow[t]{2}{*}{\begin{tabular}{l}
$\circ$ \\
$\stackrel{\circ}{\circ}$ \\
\hdashline
\end{tabular}} & $51 \mathrm{~g}^{*}$ & \multirow[t]{2}{*}{ 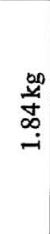 } & $\begin{array}{r}95^{*} \\
340^{*}\end{array}$ & $147 \mathrm{~g}$ & $24 \mathrm{~kg}$ \\
\hline $\begin{array}{l}\text { zircon } \\
\text { apatite }\end{array}$ & $\begin{array}{l}415 \mathrm{mg} \\
325 \mathrm{mg}\end{array}$ & & $\begin{array}{l}113 \mathrm{mg} \\
110 \mathrm{mg}\end{array}$ & & $\begin{array}{c}8 \mathrm{mg} \\
2.6 \mathrm{~g}\end{array}$ & & $\begin{array}{r}91 \mathrm{mg} \\
200 \mathrm{mg}\end{array}$ & & $\begin{array}{l}1.76 \mathrm{~g} \\
2.24 \mathrm{~g}\end{array}$ & $\begin{array}{r}2 \mathrm{mg} \\
65 \mathrm{mg}\end{array}$ & $\begin{array}{l}\text { no } \\
\text { yield }\end{array}$ \\
\hline
\end{tabular}

* Weight of fraction having purity of above $95 \%$.

Table 3. Results of ionium dating for pyroclastic flows in southern Kyushu compared with ${ }^{14} \mathrm{C}$ and fission track ages

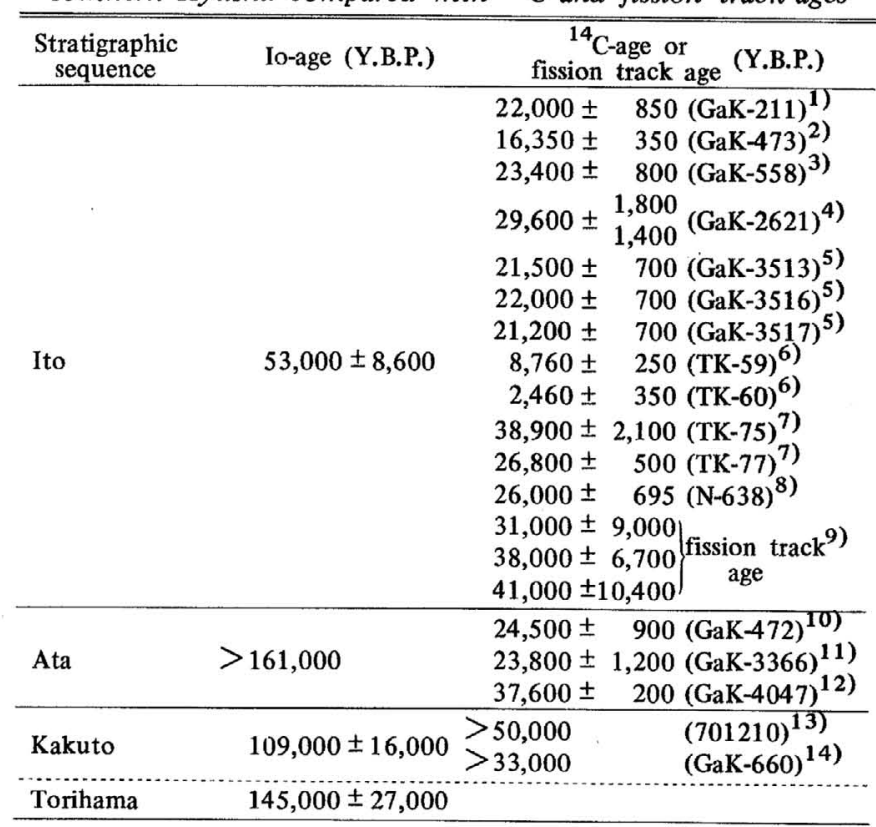

1) Gohara (1965), 2) ARAmaki (1965), 3) ISSHIKI et al. (1965), 4) Hoshino (1971),

5) KIGOSHI et al. (1972), 6) SATO et al. (1971), 7) H. KOBAYASHI et al. (1971),

8) YoKOYAMA (1971), 9) SATO et al. (1972), 10) ARAMAKI and UI (1965), 11) UI (1972), 12) ONO (1973), 13) TANEDA and MIYACHI (1971), 14) ARAMAKI (1969). 
reproduced in Table 3 and concluded that the most probable ${ }^{14} \mathrm{C}$-age for Ito pyroclastic flow was about 22,000 Y.B.P. If it is the case, the Io-age for Ito pyroclastic flow may be slightly older than the ${ }^{14} \mathrm{C}$-age. The Io-age for Kakuto pyroclastic flow is consistent with ${ }^{14} \mathrm{C}$-ages. The Io-age for Ata pyroclastic flow, on the other hand, is much older than the ${ }^{14} \mathrm{C}$-ages (Table 3 ). This Io-age is also older than Io-ages for Kakuto and Torihama pyroclastic flows which underlie Ata pyroclastic flow deposits. This suggests that the Io-age for Ata does not show actual eruption time. The details of this discordant Io-age are discussed in FukuoKA and Kigoshi (1974). Except the Ioage for Ata pyroclastic flow, all other Io-ages are consistent with the stratigraphic sequence.

In conclusion, (1) Io-ages for Ito, Kakuto and Torihama pyroclastic flows are in agreement with ${ }^{14} \mathrm{C}$ and fission track ages and consistent with the stratigraphic sequence. (2) It is suggested that when volcanic glass and zircon are available, this pair is the best for ionium dating among all possible combinations of minerals in acidic volcanic rocks. The large difference observed in this study between $U / T h$ activity ratios in coexisting glass and zircon is extensively discussed elsewhere (FUKUOKA and KIGOSHI, 1974) on the basis of partitioning behaviors of uranium and thorium.

\section{ACKNOWLEDGMENTS}

The author is much grateful to Profs. K. KIGOSHI and H. NAGASAWA of Gakushuin University for their useful suggestions; to Prof. S. ARAMAKI of the Earthquake Research Institute, University of Tokyo, Dr. T. UI of Yamagata University, Prof. K. KoBAYASH of Shinshu University and late Prof. I. KuWASHIRo of Kagoshima Women's College for their supports of sample collections and their useful geological suggestions; to Dr. A. TEZUKA and Mr. M. MORIOKA for aid in neutron activation analysis; and to Messrs. K. ONOE and I. HATANO of Gakushuin University for aid in mineral separation. This work was supported in part by grants from Matsunaga Science Foundation.

\section{REFERENCES}

ARAMAKI, S. (1963) Geology of Asama volcano. J. Fac. Sci. Tokyo Univ. Sec. II. 14, 229-443.

ARAMAKI, S. (1965) ${ }^{14} \mathrm{C}$ age of Ito pyroclastic flow of Aira caldera. Chikyu Kagaku (Earth Science) No.80, 38 (in Japanese).

ARAMAKI, S. (1969) Geology and pyroclastic flow deposits of the Kokubu area, Kagoshima Prefecture. J. Geol. Soc. Japan 75, 425-442 (in Japanese).

AramaKI, S. and UI, T. (1965) ${ }^{14} \mathrm{C}$ age of Ata pyroclastic flow. Chikyu Kagaku (Earth Science) No.80, 37 (in Japanese).

ARAMAKI, S. and UI, T. (1966) The Aira and Ata pyroclastic flows and related caldera and depressions in southern Kyushu, Japan. Bull. Volcan. 29, 29-48.

Attree, R. W., Cabell, M. J., Cushing, R. L. and Pieroni, J. J. (1962) A calorimetric determination of the half-life of thorium- 230 and a consequent revision to its neutron capture cross section. Can. J. Phys. 40, 194-201.

Cerrai, E., Lonati, R. D., GazZarrini, F. and Tongiorgi, E. (1965) Il metodo ionio/uranio per la determinazione dell'eta' di minerali vulcanici recenti. Rend. Soc. Mineral. Ital. 
21, 47-62 (in Italian).

FukUoKA, T. and KIGOSHI, K. (1970) Ionium dating for volcanic ejecta. Bull. Volcan. Soc. Japan, 2nd ser. 15, 111-119 (in Japanese).

FUKUOKA, T. and KIGOSHI, K. (1974) Discordant Io-ages and the uranium and thorium distribution between zircon and host rocks. Geochem. J. 8, 117-122.

GoHARA, Y. (1965) The active age of Aira volcano. Chikyu Kagaku (Earth Science) No.76, 33, (in Japanese).

GOLDBERG, E. D. and KoIDE, M. (1962) Geochronological studies of deep sea sediments by the ionium/thorium method. Geochim. Cosmochim. Acta 26, 417-450.

HosHINO, Y. (1971) Some problems on the geomorphic development in the Miyazaki Plain, southern Kyushu. Quat. Res. 10, 99-109 (in Japanese).

Isshiki, N., ONO, K., HiRAYAmA, J. and OTA, R. (1965) ${ }^{14} \mathrm{C}$ age determination. Geology Monthly (Chishitsu News, a review journal of Geological Survey of Japan) No.133, 20-27 (in Japanese).

KANEOKA, I. and SUZUKI, M. (1970) K-Ar and fission track ages of some obsidians from Japan. J. Geol. Soc. Japan 76, 309-313.

Kaufman, A., Broecker, W. S., KU, T. L. and Thurber, D. L. (1971) The status of Useries methods of mollusk dating. Geochim. Cosmochim. Acta 35, 1155-1183.

KIGOSHI, K. (1967) Ionium dating of igneous rocks. Science 156, 932-934.

Kigoshi, K., FukuoKa, T. and Yokoyama, K. (1972) ${ }^{14} \mathrm{C}$ age of Tsumaya pyroclastic flow, Aira caldera, southern Kyushu, Japan. Bull. Volc. Soc. Japan, 2nd ser. 17, 1-8 (in Japanese).

KOBAYASHI, K., KoBAYASHI, T. and SHIMIZU, H. (1971) Tephrochronology by volcanic products from Mt. Ontake, central Japan. Memorial papers of Prof. H. TAKEHARA, 191-218 (in Japanese).

KobaYASHI, H., MATSUI, Y. and SUZUKI, H. (1971) University of Tokyo radiocarbon measurements IV. Radiocarbon 13, 97-102.

Kuptsov, V. M., Chedyntsev, V. V., KuZ'MinA, E. A. and SulerzhitskiY, L. D. (1969) Ionium ages and the process of formation of volcanic rocks. Geochem. Intern. 6, 671-675.

ONO, K. (1973) ${ }^{14} \mathrm{C}$ age of Ata pyroclastic flow, Southern Kyushu. Bull. Volcan. Soc. Japan 2nd ser. 18, 95 (in Japanese).

SATo, J., SATo, T., M ATSUI, Y, and SUZUKI, H. (1971) University of Tokyo radiocarbon measurements III. Radiocarbon 13, 94-96.

SATO, K., ARAmaKI, S. and SATO, J. (1972) ${ }^{14} \mathrm{C}$ and fission track age measurements of some volcanic products in southern Kyushu. Geochem. J. 6, 11-16.

SHIMA, M. (1967) Fission track and alpha-particle recoil track dating. Quat. Res. 6, 134140 (in Japanese).

SUZUKI, M. (1970) Fission track dating and uranium contents of obsidian (II). ibid. 9, 1-6 (in Japanese).

TADDEUCCI, A., BRoECKER, W. S. and ThURBER, D. L. (1967) ${ }^{230}$ Th dating of volcanic rocks. Earth Planet. Sci. Lett. 3, 338-342.

TANEDA, S. and MIYACHI, M. (1971) ${ }^{14} \mathrm{C}$ age of the upper part of the Kakuto pyroclastic flow, Kumamoto Prefecture. J. Geol. Soc. Japan 77, 339-400 (in Japanese).

TEZUKA, A. (1972) Uranium and thorium contents and uranium distribution in igneous apatite. Chikyukagaku (Geochemistry) 5, 28-37 (in Japanese).

UI, T. (1971) Genesis of magma and structure of magma chamber of several pyroclastic flows in Japan. J. Fac. Sci. Tokyo Univ. Sec. II. 18, 53-127.

UI, T. (1972) Tree mould and ${ }^{14} \mathrm{C}$ age of the Ata pyroclastic flow deposit, southern Kyushu. $J$. 
Geol. Soc. Japan 78, 53-54 (in Japanese).

Wakita, H., Nagasawa, H., Uyeda, S. and KunO, H. (1968) Uranium, thorium and potassium contents of possible mantle materials. Geochem. J. 1, 183-198.

YABUKI, H. and SHIMA, M. (1970) Fission track dating of zircon in the Quaternary period. Rep. Inst. Phys. Chem. Res. 46, 59-62 (in Japanese).

Yокочама, K. (1971) ${ }^{14} \mathrm{C}$ age of Ito pyroclastic flow of Aira caldera. Chikyu Kagaku (Earth Science) 25, 45-46 (in Japanese). 